\title{
Acta
Biochimica
Polonica
}

Vol. 48 No. 4/2001

$1051-1060$

QUARTERLY

\section{The effect of methotrexate on actin and invasiveness of hepatoma Morris 5123 cells in culture}

\author{
Magdalena Otrocka $^{1}$, Hendrik Verschueren $^{2}$ and Maria Malicka-Błaszkiewicz ${ }^{1}$ \\ ${ }^{1}$ Department of Cell Pathology, Institute of Biochemistry and Molecular Biology, University of \\ Wrocław, Wrocław, Poland; ${ }^{2}$ Pasteur Institut, Brussel, Belgium
}

Received: 6 November, 2001; accepted 4 December, 2001

Key words: actin, hepatoma Morris 5123, methotrexate, invasiveness

\begin{abstract}
Monomeric (G), total (T) and filamentous (F) actin and the state of actin polymerisation (F:G) were determined and actin filaments were visualized in hepatoma Morris 5123 cells cultured in the presence of methotrexate (MTX) at various concentration. The exposure of the cells to this drug resulted in a decrease of total and polymerised actin in cytoplasm and in some changes in actin filament organization. This coincided with a decrease of the cells' ability to migrate through Matrigel coated filters and with inhibition of tumour formation after reimplantation of the methotrexate treated cells to experimental rats.
\end{abstract}

Actin is one of the most abundant proteins occurring in all eucaryotic cells. It is a major component of the cytoskeleton, and is involved in many cellular functions, including cell motility, contractile ring formation during cytokinesis, maintenance of cell shape and signal transduction [1, 2]. Defects in any of these processes resulting from changes in the actin cytoskeleton are likely to lead to clinical consequences [1]. Alterations in actin organization are known to accompany malignant transformation of many cell types [3-5]. Dis- ruption of actin stress fibres occurs in many cancer cells. This could result from changes in actin content, but also in the level of polymerisation, indicating a disturbance of the physiological equilibrium between actin assembly and disassembly, so important for its functions. On the other hand, the disappearance of stress fibres could also result from a defect in the aggregation of filaments into bundles, rather than in the actual amount of filamentous actin.

\footnotetext{
The studies were supported by the research grant from the University of Wrocław, No. 1013/S/IBCH.

${ }^{\square}$ Corresponding author: Maria Malicka-Błaszkiewicz, Department of Cell Patology, Institute of Biochemistry and Molecular Biology, University of Wrocław, S. Przybyszewskiego 63/77, 51-148 Wrocław, Poland; tel. (48 71) 375 6205; fax: (48 71) 375 6234, e-mail: mmb@ibmb.uni.wroc.pl
}

Abbreviations: DMEM, Dulbecco's modified Eagle's medium; MG, Matrigel; MTX, methotrexate; $\mathrm{NaCl} / \mathrm{P}_{\mathrm{i}}$, phosphate-buffered saline; $\mathrm{PET}$, polyethyleneterphtalate. 
Interesting data are accumulating on the relation between actin organization and the ability of cancer cells to disseminate and form metastases. Changes in actin distribution were observed in populations of sarcoma cells differing in metastatic potential [6]. Similar observations were made on Madine Darby Canine Kidney (MDCK) cells transformed with Moloney sarcoma virus [7], human salivary gland adenocarcinoma [8], and melanocytic cells [9]. The invasive variants of these cells contained no stress fibres in contrast to their non-invasive counterparts which showed a high level of organization of the actin cytoskeleton. In addition to modified actin organization, changes in actin polymerisation have also been reported. Verschueren et al. [10] found that an increased $\mathrm{F}$ actin content was correlated with increased motility and malignancy of T-lymphoma cells. In these cells a high level of actin polymerisation was considered to be a prerequisite for pseudopodia formation, a phenomenon necessary for infiltration of cancer cells into a tissue. The in vitro motility and invasiveness of the lymphoma cells were decreased by inhibitors of actin polymerisation such as Clostridium botulinum C2 toxin and cytochalasin B [11, 12]. Interestingly, various types of malignant cells were also found to be more sensitive to cytochalasin B than their normal counterparts [13]. Taken together the data suggest that whereas the assembly of microfilaments into thick bundles is deficient in malignant cells, the polymerisation of actin into filaments is increasing with progression of the cells towards a more malignant phenotype. Similarly, we have observed previously an increase, both in the amount of actin and in the level of actin polymerisation, during rapid growth of hepatoma Morris 5123 experimental tumour in rats. This increase coincided with the onset of metastasis formation in the lungs of tumour bearing rats [14, 15].

In the light of these findings, selective targeting of actin filaments in cancer chemotherapy seems to be a very attractive approach. In fact, some natural marine toxins that affect actin polymerisation and filamentous actin architecture, like lantrunculins, jasplakinolide, misolinolide $\mathrm{A}$, and swinholide $\mathrm{A}$ have been described recently as compounds with anticancer potential [16-18].

Methotrexate (MTX), the drug widely used in cancer therapy, has an essential role in the treatment of such diverse neoplasms as acute lymphocytic leukemia, non-Hodgkin's lymphoma, osteosarcoma, choriocarcinoma, head, neck and breast cancers [19, 20]. The drug is also used in the treatment of a variety of non-neoplastic diseases [21]. Injection of MTX to rats with growing hepatoma Morris 5123 tumours (one week after tumour implantation) resulted in a visible inhibition of tumour growth and inhibition of metastasis formation. In the presence of the drug the increase in total and polymerised actin, characteristic for the second week of tumour growth in untreated animals, did not occur [22].

To study the effect of MTX directly on tumour cells, we have established in our laboratory the cell line derived from the rat hepatoma Morris 5123. The level of monomeric, total and filamentous actin (and by inference the level of polymerisation) were determined in the cytosolic fraction of cultured hepatoma cells, and actin filament organisation was visualised following cells treatment with various concentrations of MTX. In addition, the effect of MTX on the invasiveness of these cells was investigated in an in vitro invasion assay.

\section{MATERIALS AND METHODS}

The experiments were carried out with cultured cells derived from the rapidly growing hepatoma Morris 5123 tumour. Samples were taken from tumours growing on the left limb of Buffalo rats [23], in the second week of tumour growth.

Isolation and culture of hepatoma Morris 5123 cells. Cells were collected from the 
tumour by biopsies by the cold cocktail method [24]. The cells were washed with culture medium supplemented with double strength penicillin $(200 \mathrm{U} / \mathrm{ml})$ and streptomycin $(0.2 \mathrm{mg} / \mathrm{ml})$, transferred into sterile dishes and cut into small pieces. Minced tissue was placed in a conical centrifuge tube with cold enzymatic cocktail I (0.25\% trypsin and $200 \mathrm{U} / \mathrm{ml}$ collagenase mixed in a $2: 1 \mathrm{ra}-$ tio) and kept on ice for $4 \mathrm{~h}$. Then the tube was transferred to a warm water bath $\left(37^{\circ} \mathrm{C}\right)$ and vigorously shaken. After $2 \mathrm{~min}$ the liquid phase, which contained the dispersed cells, was transferred to a tube with culture medium and centrifuged for $3 \mathrm{~min}$ at $80 \mathrm{~g}$, at room temperature. Meanwhile the tube containing the rest of tissue was replenished with the enzyme cocktail II $(0.25 \%$ trypsin, 200 $\mathrm{U} / \mathrm{ml}$ collagenase and $1 \mathrm{mg} / \mathrm{ml}$ DNase I mixed in a 2:1:0.05 ratio), returned to the water bath and shaken. Again the fluid containing the dispersed cells was transferred to the tube with culture medium and centrifuged as above. Finally all cells were pooled, washed with the same medium, centrifuged, resuspended in medium and seeded in culture flasks at a density of $1-2 \times 10^{5} / \mathrm{ml}$.

Cells were cultured in Dulbecco's Modified Eagle's Medium (DMEM) supplemented with $10 \%$ Newborn Calf Serum (NCS), glutamine and antibiotics (100 U/ml penicillin $+0.1 \mathrm{mg}$ / $\mathrm{ml}$ streptomycin) at $37^{\circ} \mathrm{C}$ and $5 \%$ of $\mathrm{CO}_{2}$, and passaged at subconfluence using trypsin/ EDTA solution. The cells were used for the current experiments between the 5th and 15th passage.

The viability of the cells was examined before every experiment by trypan blue staining.

MTX treatment. Powdered methotrexate (Sigma, 98\% of HPLC purity) was dissolved in $0.1 \mathrm{mM} \mathrm{NaOH}$ to a concentration of $1 \mathrm{mM}$ and sterilized by filtration. Freshly prepared MTX solution was then diluted to the required concentrations $(0.1 \mu \mathrm{M}, 1 \mu \mathrm{M}$ and $10 \mu \mathrm{M})$ with DMEM without serum. The medium containing MTX was added to the growing hepatoma
Morris 5123 cells three days after cells seeding $(10 \mathrm{ml}$ per $10 \mathrm{~cm}$ diameter tissue culture dish). After $24 \mathrm{~h}$ of exposure to the drug the cells were harvested with a rubber policeman or trypsin/EDTA treatment depending on further experiments.

Reimplantation of hepatoma Morris 5123 cells. Untreated cells and cells cultured in the presence of MTX were harvested from the culture dishes using a rubber policeman, suspended in $\mathrm{NaCl} / \mathrm{P}_{\mathrm{i}}$ buffer and pelleted by centrifugation. Then the cells were resuspended in a small amount of $\mathrm{NaCl} / \mathrm{P}_{\mathrm{i}}$ buffer, counted, and $3 \times 10^{6}$ living cells were injected into the left limb of the rats. After 4 weeks the tumours were resected and weighed.

Invasion assay. The invasiveness of hepatoma Morris 5123 cells was evaluated in an invasion assay according to Albini et al. [25] with the following modifications. The Falcon Membrane Systems with inserts consisting of polyethyleneterephtalate (PET) filters with $8.0 \mu \mathrm{m}$ pore size, were coated with $100 \mu \mathrm{l}$ Matrigel (MG) diluted with DMEM to a concentration of $0.3 \mathrm{mg} / \mathrm{ml}$, then $4 \times 10^{4}$ living cells (per filter) were added to the upper chamber of each unit and incubated at $37^{\circ} \mathrm{C}$ and $5 \%$ of $\mathrm{CO}_{2}$. At the end of the incubation time the filters were gently washed with $\mathrm{NaCl} / \mathrm{P}_{\mathrm{i}}$ buffer and cells were fixed and stained with 0.125\% Coomassie Brilliant Blue in 50\% methanol and $10 \%$ acetic acid. The cells from the upper surface of the filters were removed by wiping with a cotton swab. The cells of the lower surface were counted in 10 microscopic fields (under $100 \times$ magnification). Each assay was performed in triplicate. The invasiveness factor was calculated as the percentage of cells seeded onto the upper chamber of the insert which had passed to the lower surface of the filter.

Isolation of cytosolic fractions. Cytosolic fractions were prepared as described earlier by Malicka-Błaszkiewicz \& Roth [26]. Cells grown in tissue culture dishes were gently washed with $\mathrm{NaCl} / \mathrm{P}_{\mathrm{i}}$ buffer, scraped with a 
rubber policeman and suspended in G actin stabilizing buffer (freshly made) containing $10 \mathrm{mM}$ Tris/ $\mathrm{HCl} \mathrm{pH} \mathrm{7.4,} 0.25 \mathrm{M}$ sucrose, $1 \mathrm{mM}$ dithiothreitol, $0.1 \mathrm{mM}$ ATP, $0.1 \mathrm{mM}$ $\mathrm{CaCl}_{2}$. Cells were centrifuged (100 g, $3 \mathrm{~min}$, $4^{\circ} \mathrm{C}$ ) and homogenized with 3 volumes of the same freshly made buffer in a Dounce homogeniser. Homogenates were centrifuged at $105000 \times \boldsymbol{g}$ for $1 \mathrm{~h}$ at $4^{\circ} \mathrm{C}$. The high-speed centrifugation supernatant was used as cytosolic fraction and kept frozen $\left(-70^{\circ} \mathrm{C}\right)$ until actin determination.

Actin measurement. Actin determination was based on its inhibiting effect on DNase I from bovine pancreas under standard assay conditions, as described by Malicka-Błaszkiewicz \& Roth [26]. The concentration of monomeric actin (G) was estimated by DNase I inhibition, directly in crude cytosol sample. Total actin (T) content was measured after dilution of samples with the $G$ actin stabilizing buffer until maximal inhibition of DNase I was reached [26, 27]. Filamentous actin (F) was calculated by subtracting the amount of $G$ actin from the total actin $(\mathrm{F}=\mathrm{T}-\mathrm{G})$. The state of actin polymerisation was defined by the $\mathrm{F}$ : $\mathrm{G}$ actin ratio ( $\mathrm{F}: \mathrm{G})$.

One unit of DNase I inhibitor (actin) is the amount which decreases the activity of $20 \mathrm{ng}$ of DNase I by $10 \%$ under standard assay conditions [26]. Actin concentration was expressed in units of DNase I inhibitor per $1 \mathrm{mg}$ of sample protein.

Protein. Protein was determined by the standard Lowry et al. procedure [28].

Fluorescence staining of actin microfilaments. Cells grown on cover slips were fixed with $4 \%$ paraformaldehyde in $20 \mathrm{mM}$ Pipes buffer containing $80 \mathrm{mM} \mathrm{KCl}, 1.5 \mathrm{mM}$ $\mathrm{MgCl}_{2}, 1.5 \mathrm{mM} \mathrm{CaCl} 2,10 \mathrm{mM}$ EGTA, $5.6 \mathrm{mM}$ glucose [29] for $10 \mathrm{~min}$ at room temperature and then permeabilized with $0.2 \%$ Triton $\mathrm{X}-100$ in $\mathrm{NaCl} / \mathrm{P}_{\mathrm{i}}$ buffer for $10 \mathrm{~min}$. Staining with rhodamine-conjugated phalloidin was carried out for $30 \mathrm{~min}$. After being washed with $\mathrm{NaCl} / \mathrm{P}_{\mathrm{i}}$ buffer the cells were mounted in fluorescent mounting buffer and microfila- ments were observed under fluorescence microscope Olympus BHS or confocal laser scanning fluorescence microscope LSM 510 Zeiss.

\section{RESULTS}

Actin in hepatoma Morris 5123 cells treated with MTX

Hepatoma Morris cells were cultured in conditions initially established in our laboratory. The effect of different concentrations of MTX on different actin pools and actin filament organisation was examined. Differential interference contrast (DIC) microscopy was used to observe cell morphology and fluorescence microscopy was applied to visualise actin filament distribution in the cells. Figure 1 represents a typical microscopic view of hepatoma Morris cells cultured for 3 days, showing their shape and microfilament organisation.

No statistically significant changes in monomeric actin (G) level were observed in the cytosolic fraction of hepatoma Morris after MTX treatment, but the level of total and filamentous actin as well as the $\mathrm{F}: \mathrm{G}$ ratio were decreased in the cells treated with $1 \mu \mathrm{M}$ or 10 $\mu$ M MTX (Fig. 2).

The confocal laser scanning fluorescence microscopy was applied to investigate the effect of MTX on actin filament architecture. Figure 3 presents organisation of actin filaments in hepatoma Morris 5123 cells treated with the drug as compared with the nontreated cells. In the cells treated with MTX as well as in the control (nontreated) cells actin did not form "stress fibres" but the short filaments were organised as a meshwork and were dispersed within the cell body. However, in control cells microfilaments were more "regularly" distributed, accumulated mainly under the membrane and around the nucleus, whereas in the cells exposed to MTX the filamentous actin accumulated in patches appearing randomly in the cell body (see Fig. 3). 

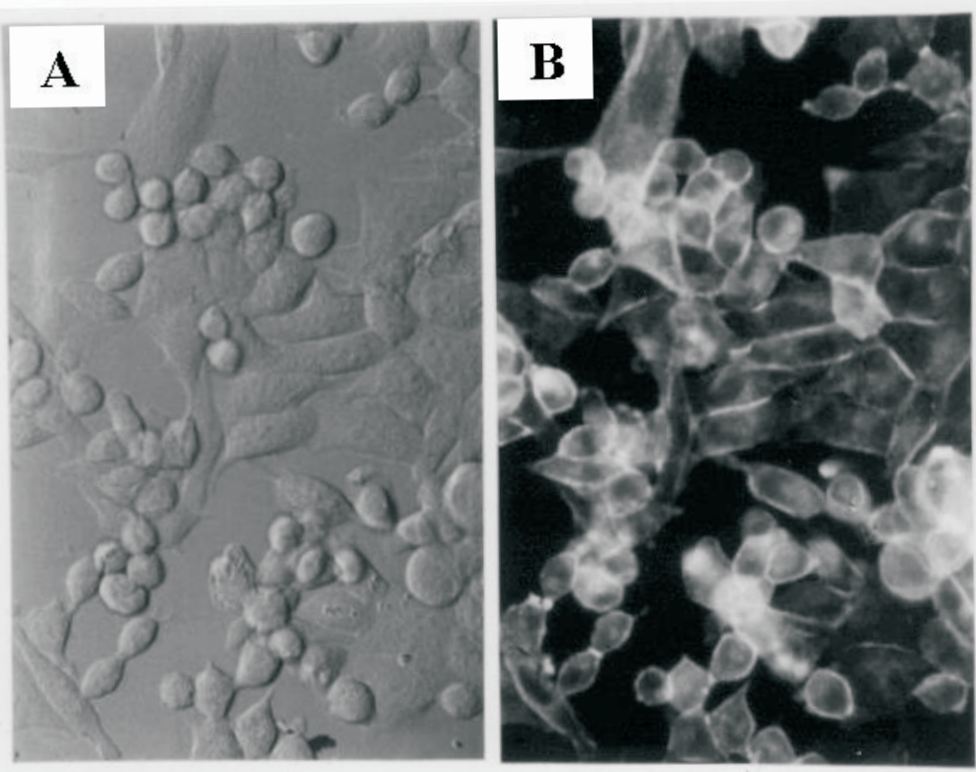

Figure 1. Hepatoma Morris 5123 cells.

A, as observed under differential interference contrast (DIC), B, actin microfilaments visualised in the same cells by rhodamine-phalloidin fluorescence staining (Olympus BHS microscope., magnification $380 \times$ ).

The effect of MTX on hepatoma Morris 5123 cell growth after reimplantation

To check the tumour forming ability of cultured hepatoma Morris 5123 cells treated with MTX, they were harvested and $3 \times 10^{6}$ viable cells were implanted to the left limb of experimental rats. Reimplanted cells were able to form tumours with an average mass of $18.7 \pm 5.2 \mathrm{~g}$ within four weeks after implantation. As seen in Fig. 4, pretreatment with
MTX decreased the ability of the cells to form tumours. An important, statistically significant decrease of the tumour mass was observed after implantation of cells treated with either $1 \mu \mathrm{M}$ or $10 \mu \mathrm{M}$ MTX.

\section{The effect of MTX on invasiveness of} hepatoma Morris 5123 cells

The invasiveness of hepatoma Morris 5123 cells cultured in vitro was evaluated by assess-
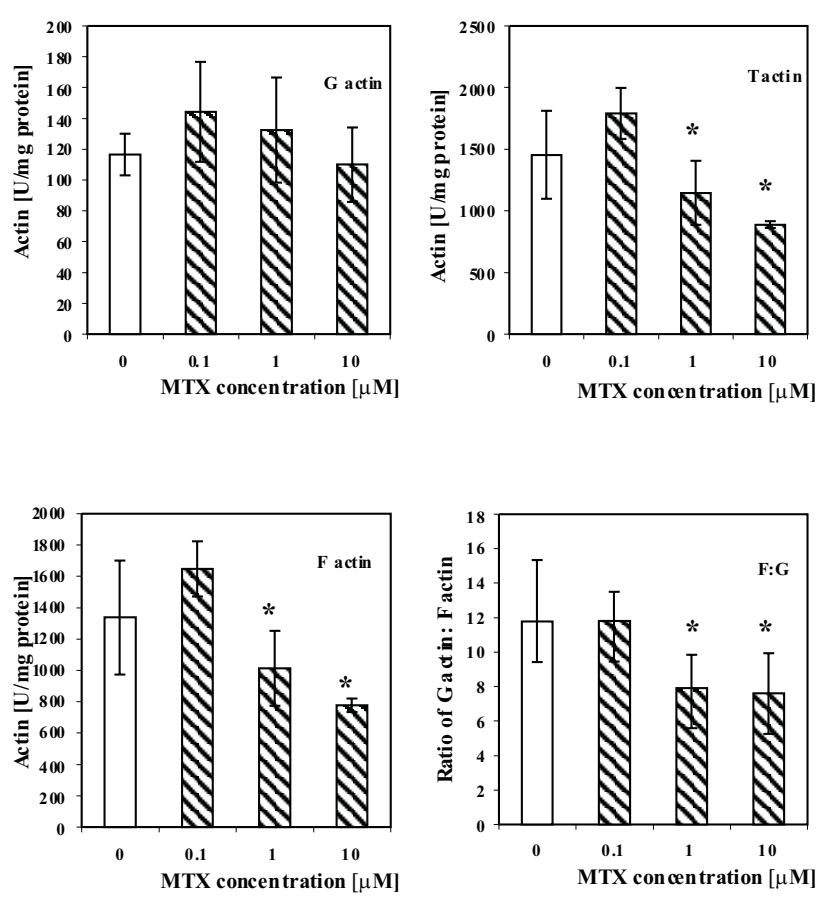

Figure 2. The effect of MTX on actin in hepatoma Morris 5123 cells.

Actin was measured as an inhibitor of DNase I from bovine pancreas (see Materials and Methods). Bars represent the mean \pm S.D. for data obtained from independent experiments. *indicates values significantly different from those for control cells (non-treated with MTX) as calculated by Student's $t$-test, $P<0.05$; $\mathrm{n}=5$ for control and the cells treated with $1 \mu \mathrm{M}$ MTX and $\mathrm{n}=3$ for the cells treated with 0.1 $\mu \mathrm{M}$ or $10 \mu \mathrm{M}$ MTX. 

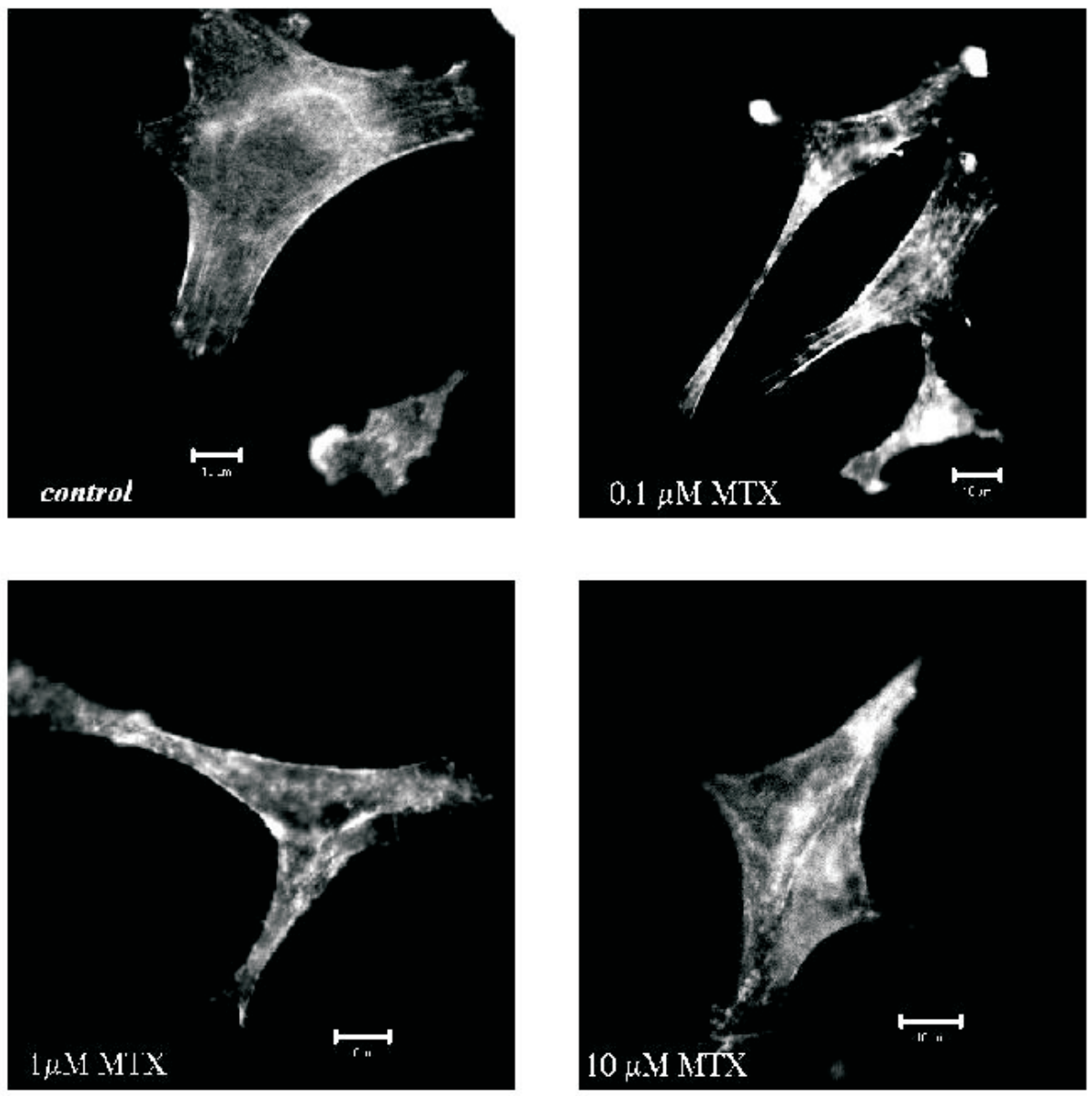

Figure 3. The effect of MTX on actin filament organisation in hepatoma Morris 5123 cells in culture.

Filamentous actin was stained as in Fig.1B and observations were done in confocal laser scanning fluorescence microscope (LSM 510 Zeiss - objective $40 \times$ ).

ing the number of cells that were able to pass through Matrigel (MG) coated PET filters

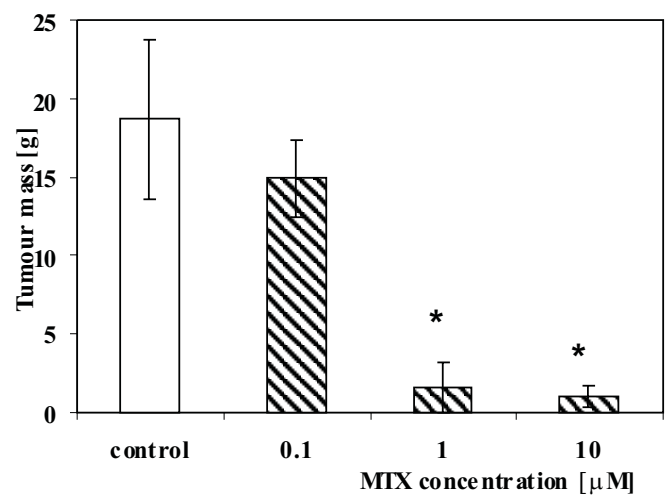

Figure 4. The mass of tumour grown after reimplantation of hepatoma Morris 5123 cells treated in vitro with different MTX concentrations.

Bars represent the mean of 3 different experimental values. *Indicates results significantly different from those for control cells, non-treated with MTX $(P<0.05)$. with a pore size of $8 \mu \mathrm{m}$. The number of cells present on the lower surface of the filters progressed with the time of incubation (Fig. 5A). The invasiveness, expressed as a percentage of cells able to pass through the MG coated filters, reached a maximum (25\%) after $48 \mathrm{~h}$ (Fig. 5A). The ability of the hepatoma Morris cells to migrate through PET filters was found to be very sensitive to MTX. Cells that were precultured for $24 \mathrm{~h}$ in the presence of $0.1 \mu \mathrm{M}$, $1 \mu \mathrm{M}$ or $10 \mu \mathrm{M}$ MTX displayed a significantly decreased ability to pass through the filters, as compared with untreated controls (Fig. 5B). The inhibition of invasion was already obvious at $0.1 \mu \mathrm{M}$. After pretreatment with $1 \mu \mathrm{M}$ or $10 \mu \mathrm{M}$ MTX, the invasion was totally arrested. The inhibitory effect of the drug was seen in $24 \mathrm{~h}$ as well as in $48 \mathrm{~h}$ experiments (Fig. 5B). 


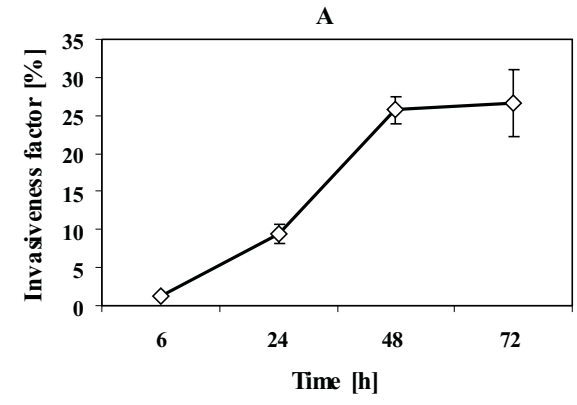

B

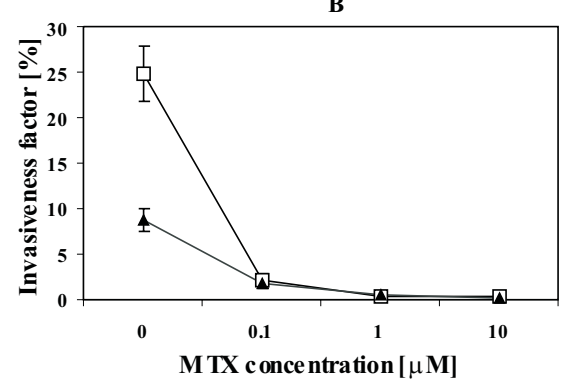

Figure 5. The invasiveness of hepatoma Morris 5123 cells measured by in vitro invasion assay.

The invasiveness factor was calculated as percentage of cells able to migrate through the Matrigel coated PET filters with $8.0 \mu \mathrm{m}$ pore size. A, the effect of time duration; B, the effect of MTX on the invasiveness in $24 \mathrm{~h}$ $(\boldsymbol{\Delta})$ and $48 \mathrm{~h}(\square)$ experiments.

\section{DISCUSSION}

The effect of drugs on actin level and its filament organisation in different cells has received increasing attention [16, 30-33]. Drugs affecting actin, used in cancer therapy, became of particular interest since the essential role of actin in motility of cancer cells and their ability to form metastases has been recognised [5, 6, 10, 12]. Interesting data were reported recently by Tikoo et al. [34] who observed a specific toxic effect of the rhodamine dye MTT-077 on several distinct human malignant cell lines, not seen on normal cells. The authors proved that the dye binds directly to actin, causing cross-linking of actin filaments and blocking of membrane ruffling.
Previous studies on the effects of MTX were focused mostly on its role as an inhibitor of dihydrofolate reductase (DHFR), the enzyme causing depletion of the reduced folate pool and subsequent inhibition of DNA synthesis and cell proliferation [19-21]. There is a single report on the inhibitory effect of MTX on invasiveness of human glioma cells [35]. However, this effect was never correlated with changes in the amount and polymerisation status of actin, nor of any other protein directly involved in cell motility.

Actin organization and polymerisation proved to play an essential role in the ability of cancer cell to invade surrounding tissues to form metastases [5, 6, 10, 12]. Presently we have shown that the inhibition of tumour formation and inhibition of invasion of hepatoma Morris 5123 cells by MTX was accompanied by changes in the actin level and in the state of actin polymerisation as measured by $\mathrm{F}: \mathrm{G}$ actin ratio and also by alterations in actin filament organisation in cells. The level of polymerised actin decreased in the cytoplasmic fraction of the tumour cells exposed to MTX at as low concentration as $1 \mu \mathrm{M}$ resulted in inhibition of tumour growth after reimplantation of the MTX treated cells to rats. Changes in the actin filament architecture and the decrease of the ability of cells to migrate through Matrigel coated filters were observed at still lower concentration of the drug $(0.1 \mu \mathrm{M})$. These differences in the response to the drug dose may result from the different sensitivity of the applied experimental tests - however, an other explanation is also possible. In the light of the presented data one can not exclude that the process of tumour growth depends to a grater extent on the actin level in cytosolic fraction, whereas the actin filament distribution in the cell, responsible for cell movement, is more sensitive to MTX treatment.

These results, especially the decrease in actin level in the cytosolic fraction, are in agreement with our former results obtained in vivo with hepatoma Morris 5123 tumours 
growing on the skeletal muscle of the left limb of experimental Buffalo rats [22]. The visible inhibition of tumour growth after intraperitonal injection of MTX was accompanied not only by a decrease in total and polymerised actin, but also by inhibition of metastasis formation in the lungs of the tumour bearing rats, which usually occured in the second week of tumour growth [22].

Our former and current results clearly demonstrate that MTX, an anticancer agent, belongs to the group of the actin affecting drugs, acting mainly on its polymerised pool. However, the molecular events underlying this effect have to be unravelled by further studies. Some preliminary experiments (not shown) indicate that MTX does not affect directly actin polymerisation in vitro. This may suggest some other mechanism of MTX action e.g. inhibition of actin polymerisation regulatory pathways.

The definition of appropriate cell culture conditions to establish cancer cell lines, like we have done in the case of the hepatoma Morris 5123, can be recommended as an advantageous tool for studying the effect of drugs on actin level and polymerisation. In addition, our present results strengthen the idea that the drugs affecting the actin level and polymerisation should be studied more extensively with respect to their possible application for inhibition of tumour growth and metastasis formation.

We acknowledge Dr. Agata Kochman from the Department of Pathological Anatomy, Medical Academy of Wrocław for resection of hepatoma Morris 5123 tumour and reimplantation of cultured cells to the rats.

We express our gratitude to Prof. Dr. Hans-Georg Mannherz from the Institute of Anatomy and Embryology of Ruhr University (Bochum), for access to his laboratory and to the laser scanning fluorescence LSM $510 \mathrm{mi}$ croscope, and we thank his coworker $\mathrm{Mr}$ Bernhard Polzar for the help in the application of this microscope.

\section{R E F E R E N C ES}

1. Janmey, P.A. \& Chaponnier, C. (1995) Medical aspects of the actin cytoskeleton. Curr. Opin. Cell Biol. 7, 111-117.

2. Sheterline, P., Clayton, J. \& Sparrow, J.C. (1998) Protein Profile. Actin, 4th edn. pp. 1-13, Oxford University Press, New York.

3. Ben-Ze'ev, A. (1985) The cytoskeleton in cancer cells. Biochim. Biophys. Acta $\mathbf{7 8 0}$, 197-212.

4. Hansell, E.J., Frisch, S.M., Tremble, P., Murnane, J.P. \& Werb, Z. (1995) Simian virus 40 transformation alters the actin cytoskeleton, expression of matrix metalloproteinases and inhibitors of metalloproteinases, and invasive behavior of normal and ataxiatelagiectasia human skin fibroblasts. Biochem. Cell Biol. 73, 737-389.

5. Button, E., Shapland, C. \& Lawson, D. (1995) Actin, its associated proteins and metastasis. Cell Motil. Cytoskel. 30, 247-251.

6. Pokorna, E., Jordan, P.W., O'Neill, C.H., Zicha, D., Gilbert, C.S. \& Vesely, P. (1994) Actin cytoskeleton and motility in rat sarcoma cell populations with different metastatic potential. Cell Motil. Cytoskel. 28, 25-33.

7. Le, P.U., Nguyen, T.N., Drolet-Savoie, P., Leclerc, N. \& Nabi, L.R. (1998) Increased $\beta$-actin expression in an invasive Moloney sarcoma virus-transformed MDCK cell variant concentrates to the tips of multiple pseudopodia. Cancer Res. 58, 1631-1635.

8. Suzuki, H., Nagata, H., Shimada, Y. \& Konno, A. (1998) Decrease in $\gamma$-actin expression, disruption of actin filaments and alterations in cell adhesion in human salivary gland adenocarcinoma cell clones. Inter. J. Oncol. 12, 1079-1084.

9. Helige, C., Zellnig, G., Hofmann-Wellenhof, R., Fink-Puches, R., Smolle, J. \& Tritthart, H.A. (1997) Interrelation of motility, cytoskeletal organization and gap junctional com- 
munication with invasiveness of melanocytic cells in vitro. Invasion Metastasis 17, 26-41.

10. Verschueren, H., Van Der Taelen, I., Dewit, J., De Braekeleer, J. \& De Beatselier, P. (1994) Metastatic competence of BW5147 T-lymphoma cell lines is correlated with in vitro invasiveness, motility and F-actin content. $J$. Leukoc. Biol. 55, 552-556.

11. Verschueren, H., Van Der Taelen, I., Dewit, J., De Braekeleer, J., De Beatselier, P., Aktories, K. \& Just, I. (1995) Effects of Clostridium botulinum $\mathrm{C} 2$ toxin and cytochalasin $\mathrm{D}$ on in vitro invasiveness, motility and F-actin content of a murine T-lymphoma cell line. Eur. J. Cell Biol. 66, 335-341.

12. Iwazaki, R., Watanabe, S., Otaka, K., Ota, K., Ono, Y. \& Sato, N. (1997) The role of the cytoskeleton in migration and proliferation of a cultured human gastric cancer cell line using a new metastasis model. Cancer Lett. 119, 191-196.

13. Stournaras, C., Stiakaki, E., Koukouritaki, S.B., Theodoropoulos, P.A., Kalmanti, M., Fostinis, Y. \& Gravanis, A. (1996) Altered actin polymerisation dynamics in various malignant cell types: Evidence for differential sensitivity to cytochalasin B. Biochem. Pharmacol. 52, 1339-1346.

14. Malicka-Błaszkiewicz, M., Styczeń, I., Nowak, D., Hańczycowa, H., Ponikowski, P. \& Sebzda, T. (1995) Actin content and polymerisation in tumour, liver and serum of the hepatoma Morris 5123 tumour bearing rats. Mat. Med. Pol. 27, 115-118.

15. Nowak, D., Majcher, I., Kochman, A. \& Malicka-Błaszkiewicz, M. (1995) The changes in actin content and polymerisation during hepatoma Morris 5123 tumour development. J. Exp. Clin. Cancer Res. 14, 37-40.

16. Jordan, M.A. \& Wilson, L. (1998) Microtubules and actin filaments: Dynamic targets for cancer chemotherapy. Curr. Opin. Cell Biol. 10, 123-130.
17. Bubb, M.R., Spector, I., Bershadsky, A.D. \& Korn, E.D. (1995) Swinholide A is a microfilament disrupting marine toxin that stabilizes actin dimers and severs actin filaments. J. Biol. Chem. 270, 3463-3466.

18. Suenaga, K., Kamei, N., Okugawa, Y., Takagi, M., Akao, A., Kigoshi, H. \& Yamada, K. (1997) Cytotoxicity and actin depolymerizing activity of aplyronine A, a potent antitumour macrolide of marine origin, and the natural and artificial analogs. Bioorg. Medic. Chem. Lett. 7, 269-274.

19. Jolivet, J., Cowan, K.H., Curt, G.A., Clendeninn, N.J. \& Chabner, B.A. (1983) The pharmacology and clinical use of methotrexate. $N$. Eng. J. Med. 3, 1094-1104.

20.Takemura, Y. \& Jackman, A.L. (1997) Folate-based thymidylate synthase inhibitors in cancer chemotherapy. Anti-Cancer Drug 8, 3-16.

21. Laurance, J.E. \& Sandborn, W.J. (1996) Methotrexate for inflammatory bowel disease: Pharmacology and preliminary results. Mayo Clin. Proc. 71, 69-80.

22. Otrocka, M., Nowak, D., Sobczak, I. \& Malicka-Błaszkiewicz, M. (1999) The effect of methotrexate (MTX) on the changes in actin content and polymerisation during hepatoma Morris 5123 growth process. Diag. Lab. 35, 399-407.

23. Morris, H.P., Sidransky, H., Wagner, B.P. \& Dyer, H.M. (1960) Some characteristic of transplantable rat hepatoma 5123 induced by ingestion of $N$-(2-fluorenyl)phthalamic acid. Cancer Res. 20, 1252-1254.

24. Doyle, A., Griffiths, J.B. \& Newell, D.G. (1993) Basic techniques for primary cell cultures and establishment of continuous cultures; in: Cell and Tissue Culture: Laboratory Procedures, chap. 3E, pp. 2.1-2.8, John Wiley \& Sons, Chichester.

25. Albini, A., Iwamoto, Y., Kleinman, H.K., Martin, G.R., Aaronson, S.A., Kozlowski, J.M. \& 
Mcewan, R.N. (1987) A rapid in vitro assay for quantitating invasive potential of tumour cells. Cancer Res. 47, 3239-3245.

26. Malicka-Błaszkiewicz, M. \& Roth, J.S. (1981) Some factors affecting the interaction between actin leukemia L1210 cells and DNase I. Biochem. Biophys. Res. Commun. 102, 594-601.

27. Malicka-Błaszkiewicz, M. (1986) DNase-like activity and actin content in the liver of some vertebrates. Comp. Biochem. Physiol. 84B, 207-209.

28. Lowry, O.H., Rosebrough, N.J., Farr, A.L \& Randall, R.J. (1951) Protein measurement with the Folin phenol reagent. J. Biol. Chem. 193, 265-275.

29. Bond, M. \& Somlyo, A.V. (1982) Dense bodies and actin polarity in vertebrate smooth muscle. J. Cell Biol. 95, 403-413.

30.Duncan, K., Duncan, M., Alley \& M. Sausville, E. (1996) Cucurbitacin E-induced disruption of the actin and vimentin cytoskeleton in prostate carcinoma cells. Biochem. Pharmacol. 52, 1553-1560.

31. Zeng, H., Xu, Z. \& Wang, K. (1997) FT-Raman studies on the transformation of G-actin to
F-actin, the binding of cisplatin and transplantin to F-actin and the effect of conformation of F-actin. Int. J. Biol. Macromol. 20, 107-113.

32. Kruidering, M., van de Water, B., Zhan, Y., Baelde, J.J., de Heer, E., Mulder, G.J., Stevens, J.L. \& Nagelkerke, J.F. (1998) Cisplatin effects on F-actin and matrix proteins precede renal tubular cell detachment and apoptosis in vitro. Cell Death Differ. 5, 601-614.

33. Rosenblum, M. \& Shivers, R. (2000) 'Rings' of F-actin form around the nucleus in cultured human MCF7 adenocarcinoma cells upon exposure to both taxol and taxotere. Comp. Biochem. Physiol. 125, 121-131.

34. Tikoo, A., Shakri, R., Connolly, L., Hirokawa, Y., Shishido, T., Bowers, B., Ye, L., Kohama, K., Simpson, R.J. \& Maruta, H. (2000) Treatment of ras-induced cancers by the F-actin-bundling drug MKT-077. Cancer J. 3, 162-168.

35. Terzis, A.J.A., Fiskerstrand, T., Refsum, H., Ueland, P.M., Arnold, H. \& Bjerkvig, R. (1993) Proliferation, migration and invasion of human glioma cells exposed to antifolate drugs. Int. J. Cancer 54, 112-118. 